Andrzej Wicher

University of Łódź

\title{
The Discourse of Orientalism in C. S. Lewis's Chronicles of Narnia
}

\begin{abstract}
It has been stated, on the basis of certain motifs in The Chronicles of Narnia, that "like many Englishmen of his era, Lewis was unconsciously but regrettably unsympathetic to things and people Middle Eastern" (Ford 363). My task in this article would be to examine the nature of this prejudice because I generally agree that we can legitimately talk about C. S. Lewis's prejudice against Oriental cultures. The crucial problem seems to be whether this prejudice was so serious and so strong that it should in turn prejudice us, not only perhaps against what Lewis had to say about the Oriental cultures, but maybe even against this author himself. Naturally, Lewis's "antiOrientalism" is hardly subversive in relation to his own cultural background, but it would be hard to deny that it is subversive in relation to the currently dominant discourse of multiculturalism. The material for the discussion is provided, for the most part, by the thread of Calormen, a fantastic country (appearing only occasionally in The Chronicles of Narnia, mainly in The Horse and His Boy) that shares many characteristics with a certain stereotypical conception of the Oriental civilization. But also some other books by C. S. Lewis, notably his essays, are taken into account. Some reference is also made to the famous book by Edward Said, Orientalism.
\end{abstract}

When talking about Orientalism, I basically follow E. W. Said's perception of the Western way of seeing the Orient as the Other, the Other being understood in largely negative terms, though at the same time a source of fascination. This is what Said seems to have had in mind when he talked, in the same breath, about "Oriental despotism, Oriental splendor, cruelty, sensuality" (1993). Thus, it might seem that the concept of Orientalism, while being essentially conservative, in the literal sense, as it helps to conserve the traditional identity of the West, conceived of largely in contrast with the East, or Orient, is also subversive, first of all, but not only, in the sense that it subverts itself, containing elements that cannot be easily harmonized with each other. Neither is C. S. Lewis's Orientalism in The Chronicles of Narnia a simple phenomenon, though it may seem simple to many not very attentive readers.

It is clear enough that the problem of Orientalism in Lewis's The Chronicles of Narnia essentially boils down to the thread of Calormen, a fantastic country shown mainly in the part of the cycle entitled The Horse and His Boy, 
represented as lying to the south of Narnia and separated from it by a broad belt of sandy desert and also by a borderland region called Archenland, which, unlike Calormen, is usually friendly towards Narnia. It is exactly Calormen that has been endowed with certain stereotype features traditionally associated with the Western perception of the East, or rather the Middle East. The inhabitants of Calormen are thus presented as a southern race, but also vaguely Oriental. David C. Downing refers to Andrew Blake's opinion according to which "Lewis's Calormenes [are] an unkind parody of Arabs, [and] the Narnia books contribute to the contemporary "demonization of Islam" (159).

As Downing correctly observes, Lewis's Calormen cannot be regarded as, strictly speaking, a representation of an Islamic culture because it is patently polytheistic, ${ }^{1}$ but the Calormenes, nevertheless, "resemble Arabs in many respects" (159). This conclusion is no doubt suggested by the descriptions of the Calormenes' dress (turbans, shoes turned up at the toe), weapons (curving scimitars), racial type (dark faces), customs (frequent and elaborate haggling), titles (Grand Vizier), currency (the so-called crescents) and, first of all, by their manner of speaking, which is usually very formal and ornamental, full of set phrases (like "may he live for ever" when referring to the ruler of Calormen called the Tisroc) and florid quotations, possibly spurious, from unidentified poets. All of this seems to dovetail with a set of popular stereotypes about the Arabic or Oriental (possibly also Turkish, or Persian) reality, even though it is no doubt highly disputable to what extent those stereotypes correspond to any historical reality.

The above-mentioned quotations are highly sententious, platitudinous and didactic, although the morality they seem to propagate is servile, opportunistic and down-to-earth. For example, when the protagonist of The Horse and His Boy, Shasta, asks his Calormen foster father about "what is there beyond the hill," the answer he is given is apparently a quotation from "one of the poets": "Application to business is the root of prosperity, but those who ask questions that do not concern them are steering the ship of folly towards the rock of indigence" (12-13). Other examples are: "Natural affection is stronger than soup and offspring more precious than carbuncles" (15), "He who attempts to deceive the judicious is already baring his own back for the scourge" (121), "[T]he departure of guests makes a wound that is easily healed in the heart of a judicious host" (121), or "[D]eep draughts from the fountain of reason are desirable in order to extinguish the fire of youthful love" (122). If we accept the simple definition of poetry provided by Chris Baldick in his Concise Oxford Dictionary of Literary Terms: "Poetry is valued for combining pleasures of sound with freshness of ideas, whether these be solemn or comical" (173), then

${ }^{1}$ Naturally, as is well known, also the Arabs, and other Islamic nations, were usually polytheistic before they adopted Islam. 
the Calormen "poetry" may be described as anti-poetry, as it offers neither "the pleasures of sound" nor "freshness of ideas," only rather sanctimonious solemnity, and the only poetical devices it uses are well-worn metaphors. At the same time, this kind of poetry shows clear signs of belonging to the respectable genre of proverb and parable.

In his discussion of Arabic literature, Józef Bielawski suggests that collections and anthologies of parables and fables became particularly popular at the epoch in the history of Arabic literature which he calls the times of lethargy and torpor ("letarg i martwota") that apparently characterize that literature in the period extending over three centuries: the sixteenth, seventeenth and eighteenth (cf. 349-50). In his references to Calormen poetry, C. S. Lewis is no doubt recalling the experience of reading The Arabian Nights, where the characters occasionally quote apophthegmatic and didactic poetry, or simply make use of proverbs, which is only natural in popular literature to which The Arabian Nights belongs, even though it is true that this undoubtedly brilliant work was composed and became widely known at the beginning of the above-mentioned period of "torpor and lethargy." The characters in The Arabian Nights do of course many other things besides quoting ancient, or not so ancient, proverbs; they show such virtues as courage, endurance, altruism and hospitality, while the Calormenes are interested only in oppressing, exploiting, deceiving and enslaving, which is something that only negative characters in The Arabian Nights have a liking for. Besides, the poetry quoted in The Arabian Nights is not all composed of maxims and parables. Sometimes it concerns, for example, female beauty, and even if it is sententious, the sentences are not usually similar to Calormene proverbs, that is, they are not normally based on a servile and cynical morality. For instance, the first piece of poetry quoted by the wise woman Shahrazad at the very beginning of The Arabian Nights is indeed a proverb, but it attempts to give hope to those who have fallen into despair by saying that time not only takes away joy, but also human worries (17).

The point is that the southern Calormen serves in Lewis's books as a counterpoint to the northern Narnia. The former is shown as essentially a land of slaves and slave owners, that is, of people who are either abjectly subservient or intolerably haughty; in fact, they often are both subservient towards their social superiors and haughty in relation to their inferiors (if there are any), whereas the latter, i.e., Narnia, is represented as the land of the free, of people who know their own value and manage to preserve their dignity in relation to their social superiors, while avoiding riding roughshod over the feelings of their inferiors. Also the poetry of Narnia is contrasted with that of Calormen: "[T]heir poetry is not, like ours, full of choice apophthegms and useful maxims, but is all of love and war" (Lewis, Horse 129). In other words, the poetry of Calormen is that of morbid stability, while that of Narnia stands for the change, movement and risk- 
taking associated with the notions of love and war. The freedom of Narnia is of course hardly appreciated in Calormen. As Tisroc, the ruler of Calormen, puts it: "These little barbarian countries that call themselves free (which is as much as to say, idle, disordered, and unprofitable) are hateful to the gods and to all persons of discernment" (124). Freedom then, in the eyes of the slavery-loving Calormenes, is synonymous with chaos and disorder, but we are meant to understand that this "chaos and disorder" represents life, while the Calormene order and profitability is mechanical, and, in the long run, deadly and inhuman.

It is remarkable, in this context, that the most important representative of Calormen in The Horse and His Boy is a teenage upper-class girl called Aravis, who, on the whole, is a highly likeable and respectable character. She certainly may be counted among the most interesting female characters created by C. S. Lewis. Let us say immediately that what makes her interesting in the first place is her rather obviously androgynous nature. Aravis's androgyny is a result of her rejection of "pure femininity" symbolized by her highly unreliable friend Lasaraleen, who is contrasted with Aravis in much the same way as Calormen is contrasted with Narnia. Lasaraleen is basically an embodiment of all negative stereotypes connected with traditionally conceived femininity. She is extremely snobbish and egoistic, but also lazy and cowardly. She is completely absorbed in trivialities connected with all kinds of self-indulgence and mindful only of her social status. In the story, we see Lasaraleen, first of all, as a person who cannot understand Aravis's motivation for escaping from her family home where she is being forced to marry a man whom she hates and despises. What matters for Lasaraleen is only the fact that this man is rich and highly-placed in the Calormen society so he can guarantee various creature comforts, such as bathing in ass milk, for his prospective wife. Thus, her understanding of marriage is utterly cynical, but also subservient; she has nothing against being bossed about by her family or by her husband as long as this is compensated by material bonuses. Lasaraleen represents Calormen at its worst, but also, I am afraid, at its most typical, while Aravis is a highly paradoxical creature and, above all, she is a very good product of a very bad society.

Her "goodness" is closely related to her having embraced the chivalric and heroic values associated with masculine aspects of the traditional Western feudal culture. It is of course rather difficult for her, as a girl, even though she is a princess, to aspire to a chivalric ideal. Female knights were very exceptional creatures in the medieval and Renaissance tradition, although one of Lewis's favourite Renaissance books, Edmund Spenser's The Faerie Queene, contains 
the character of female knight called Britomart. Britomart is originally a Greek nymph, or goddess, closely connected with the virgin hunter Artemis, perhaps an aspect of Artemis, whom the Romans called Diana. In Spenser, however, she appears as a British figure of power, as suggested by the entirely false etymology of her name, which originally seems to have meant "good maiden," 2 and is not connected with Britain. Spenser clearly suggests that his Britomart is another embodiment of the Fairy Queen, and of the Queen Elizabeth I. Britomart, incidentally, resembles Aravis in that she also escapes from the house of her father, but her motivation is different. Instead of desiring to avoid an unwanted marriage, she rather wants to find a man whom she loves, even though she never met him and only saw his reflection in a mysterious mirror, a little like Tennyson's Lady of Shalott.

We learn the story of Aravis mainly from her own account included in chapter three of The Horse and His Boy:

Now it came to pass that my father's wife, my stepmother, hated me, and the sun appeared dark in her eyes as long as I lived in my father's house. And so she persuaded my father to promise me in marriage to Ahoshta Tarkaan. Now this Ahoshta is of base birth, though in these latter years he has won the favour of the Tisroc (may he live for ever) by flattery and evil counsels, and is now made a Tarkaan and the lord of many cities and is likely to be chosen as the Grand Vizier when the present Grand Vizier dies. Moreover he is at least sixty years old and has a hump on his back and his face resembles that of an ape. Nevertheless my father, because of the wealth and power of this Ahoshta, and being persuaded by his wife, sent messengers offering me in marriage, and the offer was favourably accepted and Ahoshta sent word that he would marry me this very year at the time of high summer. (46-47)

This sounds a little like the story of Cinderella: the young heroine is persecuted by a wicked stepmother. However, the heroine's social status is too high for her to be treated like a Cinderella; hence she is being forced to marry a rich and powerful man, but, at the same time, someone who, in most respects, is very unlike the prince charming with whom Cinderella falls in love and who, eventually, becomes her husband. The social context of the story seems purely patriarchal. In spite of her high birth, Aravis is treated like an object and never even asked if she has anything against marrying Ahoshta. At the same time, the whole situation is clearly organized and masterminded by the formidable stepmother, who manages to gain almost total control over her husband. Admittedly, she can pull off this apparently anti-patriarchal feat only because of her husband's rather pliant and docile nature. Hen-pecked husbands are quite common in the patriarchal world (making it of course a little less patriarchal),

${ }^{2}$ This is the meaning of the name Britomartis provided in Robert Graves's The Greek Myths (2: 384). I am not a Greek scholar but it seems rather difficult to arrive at this etymology on the basis of classical ancient Greek, but then Britomartis was apparently a Cretan figure (cf. Graves 1: 299-302). 
and they are a necessary ingredient of Cinderella tales and of a number of other types of folktales. While, on the one hand, weakening the patriarchal order, the strong-minded stepmother seems to confirm it, on the other, because her rule is shown as unfair and tyrannical, and without her passive husband, the monstrosity of her ambitions would have never been exposed.

Instead of suffering her lot patiently, as a conventional Cinderella figure would have done, Aravis decides to commit suicide by piercing her heart with a dagger. This gesture is abrupt, violent and dramatic, and it might befit a heroic and aristocratic man. However, it is a well-established tradition for a woman to commit suicide when faced with an unwanted, or violent, suitor, the best example of which is certainly the historical character of Lucretia, who takes her own life having been raped by Tarquin, the Roman king's son. ${ }^{3}$ Aravis is dissuaded from her hasty decision by her Narnian - and speaking - mare Hwin. Hwin inspires her with the idea of escaping to Narnia, and, first of all, with a longing for Narnia, which, in The Chronicles, is a convenient criterion by which the worthiness of a character can be judged. Those who do not pass muster, from a moral point of view, are, at the same time, hostile or indifferent to Narnia, but if one feels nostalgia for it, one is already half-saved, even though one may still have many vices. Unlike her parallel character, the boy Shasta, who is the protagonist of The Horse and His Boy, and who eventually becomes her husband, Aravis has to choose between Narnia and real death, while his choice involves only a death-like slavery. This is in fact one of the most fundamental differences between male and female characters in romances. Unlike the former, the latter are never looking for adventures; their adventures are either imposed on them, by banishment, for example, or they have to embark on a dangerous style of life because the only alternative is death. As Helen Cooper claims:

[W]omen who find themselves in a situation analogous to the hero's quest in romance are most often victims rather than agents, compelled to leave the safety of their own homes and at other people's mercy. The lone woman at large in romance is more likely to be cast adrift in a rudderless boat than to choose to follow the call of adventure. .

The situation of Aravis is in fact half way between that of a free agent following "the call of adventure" and of a passive victim "compelled to leave the safety of her home." She is "compelled," but not by means of direct, physical force, as is the case of banished heroines. On the contrary, she is compelled by her own moral sense, and leaves her home even though nobody forces her to do so; indeed she leaves it spite of those around her, with the sole exception of her faithful mare.

${ }^{3}$ Also the Cretan Britomartis, pursued by the amorous king Minos, throws herself into the sea (cf. Graves 1: 299). 
When we compare Shasta and Aravis, it is striking that the girl is, on the one hand, shown as a far more accomplished creature than her male counterpart; on the other, however, he is clearly, with all his faults, or because of them, more human and much easier to identify with. It no doubt belongs to the romance standards that female characters are often shown as idealized, but rather passive, and also here it is Shasta, and not Aravis, who has the most exciting adventures. As opposed, however, to the mainstream of the romance tradition, Aravis's accomplishments are not of a particularly feminine kind. We learn, for example, little, or nothing, about her beauty or other perfections of her outward appearance. What we do learn is that Aravis is a perfect horsewoman, an infinitely better horse rider than Shasta, which is important in a story in which most of the action is connected with horseriding. Shasta's inability to ride symbolizes his having been brought up in a fisherman's family, while Aravis's skill is naturally related to her being an upperclass girl, which she is in all kinds of ways.

Another of her talents is the ability to speak well. She is a good storyteller, which also betokens her superior education:

Aravis immediately began, sitting quite still and using a rather different tone and style from her usual one. For in Calormen, story-telling (whether the stories are true or made up) is a thing you're taught, just as English boys and girls are taught essay-writing. The difference is that people want to hear the stories, whereas I never heard of anyone who wanted to read the essays. (44-45)

This expression of the author's genuine admiration at the Calormene standards of education may sound a little strange in view of what we have already said about the generally critical, to put it mildly, vision of the Calormene society shown in this book.

Aravis has inherited a highly refined tradition, even though this tradition seems warped by excessive formality and love of empty ritual. Of course the matter is more complicated due to the fact that many Oriental, or quasi-Oriental, stereotypes also belong to the phenomenon called effeminacy. The complexity of the Orient as the Other is no doubt structurally similar to the complexity of the concept of the woman as the Other. The Calormenes often hide their rather cruel and perfidious nature behind a mask of great kindness and politeness, and such treacherousness is part of the stereotype of effeminacy, or even femininity itself. Even Aravis, who represents, in many ways, what is best in Calormen, has a streak of cruelty in her character, but, unlike the stereotypical woman, she does not particularly try to hide it, and does not even seem particularly ashamed of it:

Then I called the maid who was to go with me to the woods and perform the rites of Zardeenah and told her to wake me very early in the morning. And I became merry with her and gave her wine to drink; but I had mixed such things in her cup that I knew she must sleep for a night and a day. (50) 
Later Shasta asks her about that girl:

"And what happened to the girl - the one you drugged?" asked Shasta.

"Doubtless she was beaten for sleeping late," said Aravis coolly. "But she was a tool and spy of my stepmother's. I am very glad they should beat her."

"I say, that was hardly fair," said Shasta.

"I did not do any of those things for the sake of pleasing you," said Aravis. (53)

Eventually, Aravis is punished for her insensitivity to the sufferings of that girl by Aslan, the great lion, himself, who scratches her back with his big paw leaving five bloody marks that later heal without causing any lasting harm to the girl's health. As Aslan explains the matter to her:

The scratches on your back, tear for tear, throb for throb, blood for blood, were equal to the stripes laid on the back of your stepmother's slave because of the drugged sleep you cast upon her. You needed to know what it felt like. (216-17)

Aravis's punishment is broadly analogous to that of Sir Gawain, the hero of Sir Gawain and the Green Knight, who receives from the mysterious, frightening, but also, to some extent, fatherly, Green Knight a bloody mark on his neck to make him realize his disloyalty to the Green Knight and his falling short of the ideal of perfection that he pursues. This ideal is represented by Gawain's favourite symbol, that of pentangle, the five-pointed star, with its five points representing the five virtues of which Gawain is particularly proud. Aravis's five stripes on her back seem to represent a kind of anti-pentangle, and are a sign of her imperfection, but also of her being singled out by Aslan, who does not often take the trouble of personally chastising the people whose behaviour he might object to. It is evident that Aravis has learnt her lesson, instead of reacting haughtily, as she did when Shasta criticized her over her dealings with the slave girl. Having heard Aslan's verdict, she is now worried about the future lot of the girl she had drugged, so she asks empathetically: "Will any more harm come to her by what I did?" (217).

Without that lesson, she would never have become fit to marry Shasta, who, by now, is revealed to be the first-born son of the king of Archenland, a country neighbouring Narnia, and his real name is Cor. Aravis used to be supercilious towards Shasta, thinking herself far better educated and, first of all, much better born. Now she even seems to be angry when Shasta (or rather Cor) mentions his social inferiority consisting in his not having been given a proper aristocratic upbringing, even though one may doubt the authenticity of her having overcome her deeply ingrained snobbery; after all, she knows by now that her companion, with all his woeful educational deficiencies, is a prince of royal blood. At the same time, Cor's newly discovered aristocratic background is in keeping with the standards of chivalric romances, and the rules of that genre had a substantial 
influence on this book. The lovers in chivalric romances may start their relationship as socially mismatched, but this state of affairs is not allowed to continue, as if class solidarity were a necessary ingredient of a successful erotic relationship. The Middle English romance Havelok, the Dane is a good, though by no means unique, example of this rule, and it is, moreover, slightly similar to the story of Aravis and Shasta. The heroine of the romance is forced to marry a man of low social status, even though she is herself a princess. Later, however, it turns out that her husband is the son of a king, of which he himself at first was not aware.

Knowing that C. S. Lewis was a man steeped in Biblical lore, one can be easily tempted to interpret The Horse and His Boy along allegorical lines. The journey across the desert from the land of slavery (Calormen) to the land of freedom (Narnia) is in fact rather heavily reminiscent of the exodus of the People of Israel from Egypt to the Promised Land. Shasta is clearly a Moses figure. Exactly like Moses, he was found in a basket floating on a river. He is a Narnian brought up in the Calormene society, but treated rather coldly by that society, and feeling no loyalty to it, just as Moses was brought up as an Egyptian and later turned against Egypt and its, from his point of view, wicked ways. Aravis stands for the People of Israel itself and her name is almost an anagram of Israel. Shasta feels responsible for her and helps her a lot, even though, just like the People of Israel towards Moses, she was often ungrateful towards him.

Thus, the discourse of Orientalism, as represented by Lewis, is here made a little more complicated by exploiting the divisions within the Oriental culture itself. This brings our attention to the fact that European Orientalism was probably to quite a large extent shaped by the Jewish, and expressed in the Old Testament, perception of Egypt and other Middle Eastern empires, even though there is no denying that an even greater role must have been played in this process by the Greek conflict with the ancient Persian empire. Interestingly, both Jewish and Greek cultures, although they symbolized a resistance to Oriental despotism, were themselves in due time represented as more or less Oriental (which is perhaps more true of the Jews than of the Greeks), especially vis-à-vis Western Europe.

But Lewis was also a Christian apologist, and this fact may suggest that Shasta is, like Aslan, though in a different sense, a figure of Christ. His profession is basically that of a fisherman; he was brought up by a man who played, to some extent, the role of his father, but was not really his father, because his kingdom, and he was to become the king of Archenland, is in a different world. He also has a rather special relationship with Aslan, who treats him as if he were his favourite child. Aslan comforts him at the Tombs of Tashbaan, where Shasta is isolated and surrounded by darkness, like Christ in the Garden of Gethsemane. In other words, Shasta is to Aslan more or less what 
Aslan is to his godlike father, the mysterious Emperor-Beyond-the-Sea. Both Shasta and Aslan are rather hard on Aravis for her show of callous indifference, and Aravis, in this context, is of course the Holy Church and the Bride of Christ, in keeping with the traditional Christian interpretation of the Canticle of Canticles. Like the Shulamite woman in the Canticle of Canticles, she has, like all Calormenes, a dark complexion. Her being punished for her ruthlessness, and her meek acceptance of that punishment, shows her belonging already to the world of the New Testament, in which simple acts of revenge, or cruelty perpetrated on one's enemies, similar to the way the People of Israel treat the Egyptians who try to prevent the exodus or pursue the fleeing Israelites, are no longer tolerated. Her being presented as an excellent storyteller shows her priestly dignity because the story she tells is that of the miracle of Incarnation, ${ }^{4}$ near death and symbolical Resurrection. Lewis's admiration for the ancient People of Israel is also visible in his admiration for Aravis's accomplishments. Naturally, this analogy has its limitations; Shasta and Aravis do not have to conquer Narnia, their Promised Land, since it is already in the hands of Aslan's loyal friends and worshippers. But Narnia in Lewis's septalogy is shown as a land which, similarly to the Ancient Israel, is constantly in danger of being conquered by Aslan's enemies, and this danger, from time to time, materializes.

The Horse and His Boy has also a clearly ironical aspect. The would-be pharaoh, who pursues the fleeing party of the lovers of Narnia and whose forces are duly annihilated, is called Rabadash, and he is a son of the ruler of Calormen rather than the ruler himself. This is quite logical; it is the Old Testament that is difficult to believe on this point, since it is hard to imagine the pharaoh himself chasing after the Israelites, who were, after all, little more than a group of runaway slaves. In point of fact, Rabadash is not interested in Shasta and his tiny group, composed of two children and two talking horses. He wants to conquer Narnia and to force Susan, a queen of Narnia (there are two queens there, and two kings) to become his wife. The problem with Rabadash is that he is not only thoroughly spoilt and abominable from a moral point of view, but also exceedingly vain and easily loses touch with reality. Aslan, having helped, though rather discreetly, the armed forces of Narnia and Archenland, metes out a form of punishment to Rabadash by turning him into a donkey, and yet giving him a chance to regain his human shape. Following St. Francis, Lewis compares the human body to an ass in The Four Loves:

Ass is exquisitely right because no one in his senses can either revere or hate a donkey. It is a useful, sturdy, lazy, obstinate, patient, lovable and infuriating beast; deserving now the stick and now a carrot; both pathetically and absurdly beautiful. So the body. (117)

\footnotetext{
${ }^{4}$ She herself, in a sense, represents that miracle because of her being endowed with a simple, though not infallible, moral sense, even though educated in an amoral environment.
} 
Thus, the theme of friendship in The Horse and His Boy is inextricably connected with that of love, and both are anchored in the Biblical and Christian tradition, as well as in the tradition of the chivalric romance.

The Oriental, or rather quasi-Oriental, motifs in this book may of course be easily dismissed as based on Western prejudices and completely unreliable stereotypes. But perhaps we should ask why Lewis needed those Calormenes in this particular context. The answer seems to be that Calormen is an almost chemically pure model of a land where neither real love nor friendship are possible. The Calormenes are, in some respects, highly civilized, but they basically have no interests, apart from self-interest, and it would be extremely difficult to imagine there anybody, or any institution, that would pursue any activity that could not be motivated by narrow self-interest. That is why there does not seem to have been any artistic, educational, or scientific activity worthy of that name.

But the situation of the typical Calormenes is even worse than this; they have no real "self." They have totally adapted themselves to slavery, which means that they are closer to the condition of some animals or automata than to that of human beings. Aravis, when she conceives the intention to kill herself to avoid marrying the man she cannot love, or even respect, in fact discovers her "self" as an entity that cannot be reduced to a mere herd instinct, and will not yield to social pressure. In The Four Loves, Lewis distinguishes between two kinds of pleasures: "Now it is a very old discovery that pleasures can be divided into two classes; those which would not be pleasures at all unless they were preceded by desire, and those which are pleasures in their own right and need no such preparation" (19). He calls them "Need-pleasures" and "Appreciative Pleasures" (20). Lewis does not, naturally, condemn the Need-pleasures, but he certainly considers the Appreciative Pleasures to be of a higher kind and connected with the ability to appreciate things for the sake of their own intrinsic value, not just according to how they can help us.

It seems that Aravis's discovery of the self, or perhaps we should say, the higher self, is based on her ability to experience not so much an appreciative pleasure, but rather an appreciative displeasure. This is why she rejects disdainfully any suggestions that the marriage she spurns may bring her all kinds of material comfort, and also raise even further her social status. It is not accidental that this state of the heroic virgin's mind is connected, firstly, with the readiness to commit suicide (in this way she acknowledges that there are higher values even than one's own life, which should not be understood as approval for suicide itself) and, secondly, with the readiness to accept the "good news" from the apostle mare that there exists somewhere a kingdom of the free who never shall be slaves. 
This ability to conceive of an essentially different world, and to look at one's own world, as it were, from outside, was regarded by Romano Guardini as a crucial novelty introduced into the Western culture by the Middle Ages:

In the Middle Ages, we observe a thorough change in people's attitude toward the world, and the world view. People believe in the Biblical revelation, which makes them aware of God's reality that can be found above and beyond the world. (18)

It is of course rather difficult to say to what extent Aravis is medieval, or perhaps even post-medieval, but she is an anima naturaliter Christiana, a natural Christian, or rather Aslanian, in that she has no trouble accepting the faith in Aslan, about whom she heard nothing in Calormen, or she heard of him as an evil demon who can take the shape of a lion. It also seems important that she is an excellent horse rider, a chevalier, who has a very good rapport with her horse (which seems to stand for "natural" movement, rather than merely mechanical). She can thus move swiftly and efficiently, also in the metaphorical sense, and, without being tied to any social background, or tradition, she will move within the bounds of a harmonious relationship with nature, which is also something associated with the pre-industrial Middle Ages. Her androgyny is a fulfilment of masculine dreams about an ideal woman whose "masculinity" does not diminish her femininity, but rather purges it of those features that a man might find, especially in the long run, disagreeable in a woman. Thus, she may be censorious and hard to please, but she is not captious, petty-minded, or nagging; her aristocratic aloofness is compensated by unswerving loyalty and great courage. It is then a femininity that has been purified, or rather that is seen as purged of any obviously negative aspects, just as her friend Lasaraleen represents a femininity that has been "purged" of all "positive" aspects, that is, of such that could link her with the world of Western (or Northern) values and that of heroic masculinity.

To what extent Lewis was really prejudiced against the Orientals is not an easy matter to solve. Those who would like to jump to the easy, much too easy, conclusion that he indeed was deeply prejudiced should be warned that he, a Christian apologist, did not hesitate to call Jesus Christ an Oriental "according to the flesh" ("Petitionary Prayer" 219). He also manages to combine his firm belief in the Jews, or rather Ancient Hebrews, as he often calls them, being a "chosen people," that is, chosen by God to be receivers and transmitters of God's revelations and miracles, with the awareness that they were also Orientals. 
Lewis talks in the following way of his at first disappointing experience of reading the Old Testament Book of Proverbs:

What a dull, remote thing, for example, the Book of Proverbs seems at a first glance: bearded Orientals uttering endless platitudes as if in a parody of the Arabian Nights. Compared with Plato or Aristotle . . . it is not thought at all. Then, suddenly, just as you are going to give it up, your eye falls on the words, 'If thine enemy by hungry, give him bread to eat, and if he be thirsty give him water to drink' $(25: 21)$. One rubs one's eyes. So they were saying that already. ("Psalms" 219)

It has already been pointed out that Lewis's conception of Calormen owes much to The Arabian Nights, and it is characteristic that, in the above quotation, the Arabs and the Hebrews are treated as two forms of the same Oriental culture. But the point of course is that the "badness" and dullness of the "bearded Orientals" is represented here as a necessary concomitant of their occasionally brilliant moral insights.

This is even more clearly visible in the following quotation:

I do not at all mean that the Hebrews were just 'better' than the Greeks and the Romans. On the contrary we shall find in the Psalms expressions of a cruelty more vindictive and a selfrighteousness more complete than anything in the classics. If we ignore such passages and read only a few selected favourite psalms, we miss the point. For the point is precisely this: that these same fanatic and homicidal Hebrews, and not the more enlightened peoples, again and again - for brief moments - reach a Christian level of spirituality. It is not that they are better or worse than the Pagans, but they are both better and worse. One is forced to recognise that, in one respect, these alien poets are our predecessors, and the only predecessors we can find in all antiquity. (Lewis, "Psalms" 220)

It is therefore a matter of relatively little consequence that the Calormenes in The Chronicles of Narnia are generally presented as highly off-putting aliens whose civilization is profoundly barbarous, in spite of certain elements of refinement. What is more important is whether this barbarity is not itself a cloak that covers the Calormenes' ability to surpass the civilized peoples in some important respects. Perhaps the point of their existence, just as in the case of the ancient Hebrews, is to produce, maybe even isolated, moral values that other, more enlightened, and certainly more likeable, peoples are unable to produce.

Indeed, this unpromising culture produces two characters that seem to be able, at least partly, to redeem it: Aravis, the female knight, and the brave soldier Emeth, familiar to the readers of the last part of the Narnia tales, The Last Battle, who from a pious devotee of Tash, the Calormen god, in fact an evil demon, develops into a servant and admirer of Aslan, that is, the true God. These two examples show the peculiar genius of Calormen, a quality that we would never find in Narnia, and which consists in being the land where the miracles of incarnation and redemption are possible, where creatures apparently enslaved by 
inhuman conventions have, nevertheless, a spark of divine inspiration inside themselves that is capable of transforming them by developing their essentially noble, even though somewhat deformed, instincts. It is true that also the earthly characters, such as Edmund, Eustace, or Jill, undergo a moral transformation and a kind of awakening, but they are different in this respect from Aravis and Emeth in that they are guided all along this process by Aslan; they cannot rely on any innate qualities unlike Aravis and Emeth. It seems that the reason why this is so is because the latter are products of an essentially aristocratic society, a society which may have all the glaring faults of degenerate aristocracy but still contains a potential for developing in some chosen characters - few and far between though they are - a certain instinctive nobility. One might attribute it to Lewis's own social snobbery (he was a little proud of his Welsh aristocratic background) that he apparently did not see any possibility of salvation for those Calormenes who actually were slaves, or slave-like servants, of their horse riding masters, and who display a typical slavish mentality.

No matter how we tried to contextualize the motif of Calormen, it still remains of course a highly unpleasant place with even more unpleasant racist connotations due to its vaguely Middle Eastern look and feel. In Paul F. Ford, we find the following statement:

C. S. Lewis was a man of his time and socioeconomic class. Like many Englishmen of his era, Lewis was unconsciously but regrettably unsympathetic to things and people Middle Eastern. Thus he sometimes engages in contrasting things Narnian and things Calormene. He intends this in a broadly comic way, almost vaudevillian. But in our post-September 11, 2001, world, he would, I am sure, want to reconsider this insensitivity. (363)

Ford may be essentially right about Lewis's prejudices, but the suggestion that the terrorist activity of some of the inhabitants of the Middle East would, or perhaps even should, make this writer, or anybody, more sympathetic towards that region and its culture is, at least in my opinion, rather preposterous.

\section{Works Cited}

The Arabian Nights: Tales from a Thousand and One Nights. Trans. R. Burton. New York: Modern Library, 2004. Print. Modern Library Classics.

Baldick, Chris. "Poetry." The Concise Oxford Dictionary of Literary Terms. Oxford: Oxford University Press, 1990. Print.

Bielawski, Józef. Historia literatury arabskiej. Zarys. Wrocław: Zakład Narodowy imienia Ossolińskich - Wydawnictwo, 1968. Print.

Cooper, Helen. The English Romance in Time. Transforming Motifs from Geoffrey of Monmouth to the Death of Shakespeare. Oxford: Oxford University Press, 2004. Print.

Downing, David C. Into the Wardrobe. C. S. Lewis and the Narnia Chronicles. San Francisco: Jossey-Bass, 2005. Print. 
Ford, Paul F. Companion to Narnia. A Complete Guide to the Magical World of C. S. Lewis's The Chronicles of Narnia. San Francisco: Harper San Francisco, 2005. Print.

Graves, Robert. The Greek Myths. Rev. ed. 2 vols. London: Penguin Books, 1990. Print.

Guardini, Romano. Das Ende der Neuzeit. Ein Versuch zur Orientierung. Würzburg: Im Werkbund-Verlag, 1950. Print.

Lewis, Clive Staples. The Four Loves. London: Geoffrey Bles, 1960. Print.

---. The Horse and His Boy. London: Harper Collins, 2001. Print.

---. "Petitionary Prayer: A Problem without an Answer." Essay Collection: Faith, Christianity, and the Church. Ed. Lesley Walmsley. London: Harper Collins, 2000. 197-205. Print.

---. "The Psalms." Essay Collection: Faith, Christianity, and the Church. Ed. Lesley Walmsley. London: Harper Collins, 2000. 218-30. Print.

Said, Edward W. Introduction. "Orientalism." Norton Anthology of Theory and Criticism. Ed. Vincent B. Leitch et al. New York: Norton, 2001. 1991-2011. Print. 